Article

\title{
The Alleviating Effect of Lagerstroemia indica Flower Extract on Stretch Marks through Regulation of Mast Cells
}

\author{
Miji Yeom D, Hyanggi Ji, Jongheon Shin, Eunae Cho, De-Hun Ryu, Deokhoon Park and Eunsun Jung * $\mathbb{D}$ \\ Biospectrum, Life Science Institute, Yongin-si 16827, Korea; biout@biospectrum.com (M.Y.); \\ biocr@biospectrum.com (H.J.); biowa@biospectrum.com (J.S.); biozr@biospectrum.com (E.C.); \\ biosc@biospectrum.com (D.-H.R.); pdh@biospectrum.com (D.P.) \\ * Correspondence: bioso@biospectrum.com; Tel.: +82-070-5117-0029; Fax: +82-070-4369-3123 (ext. 16827)
}

Citation: Yeom, M.; Ji, H.; Shin, J.; Cho, E.; Ryu, D.-H.; Park, D.; Jung, E. The Alleviating Effect of Lagerstroemia indica Flower Extract on Stretch Marks through Regulation of Mast Cells. Molecules 2022, 27, 1274. https://doi.org/10.3390/ molecules 27041274

Academic Editor: Chang-Gu Hyun

Received: 26 January 2022

Accepted: 12 February 2022

Published: 14 February 2022

Publisher's Note: MDPI stays neutral with regard to jurisdictional claims in published maps and institutional affiliations.

Copyright: (C) 2022 by the authors. Licensee MDPI, Basel, Switzerland. This article is an open access article distributed under the terms and conditions of the Creative Commons Attribution (CC BY) license (https:// creativecommons.org/licenses/by/ $4.0 /)$.
Abstract: Striae distensae (SD) or stretch marks are common linear scars of atrophic skin with disintegrating extracellular matrix (ECM) structures. Although fibroblasts contribute to the construction of ECM structure in SD, some studies have reported that mast cell degranulation causes the disruption of ECM in early SD lesions. Lagerstroemia indica flower (LIF) has traditionally been used in India as a diuretic. However, little is known about the effect and molecular action of Lagerstroemia indica flower extract (LIFE) on alleviating SD. This study evaluated the effects of LIFE on mast cell degranulation and the synthesis of ECM components in fibroblasts. LIFE inhibits the adhesion of rat basophilic leukemia (RBL) cells, RBL-2H3 on fibronectin (FN) and the expression of integrin, a receptor for FN, thereby reducing focal adhesion kinase (FAK) phosphorylation. In addition, LIFE attenuated the allergen-induced granules and cytokine interleukin 3 (IL-3) through the adhesion with FN. Moreover, the conditioned medium (CM) of activated mast cells decreases the synthesis of ECM components, and LIFE restores the abnormal expressions induced by activated mast cells. These results demonstrate that LIFE suppresses FN-induced mast cell activation and promotes the synthesis of ECM components in fibroblast, which indicates that LIFE may be a useful cosmetic agent for SD treatment.

Keywords: striae distensae; stretch marks; Lagerstroemia indica; cell adhesion; mast cell activation; ECM component; fibroblast

\section{Introduction}

Striae distensae (SD) or stretch marks are common linear scars of skin. SD rarely causes major pathological problems, but from a cosmetic point of view, it imposes a psychological burden [1,2]. Most SD occurs in pregnant, adolescent, and obese women. The risk factors of SD are genetic factors, hormonal excess, and mechanical stress, but the hypotheses often conflict $[3,4]$.

SD develops pigmentation over time: the initial red linear lesions are striae rubrae (SR), while the chronic pale lesions are striae albae (SA). Histological alteration of SR shows prominent features: increase of dermal oedema between melanocytes and keratinocytes and melanogenesis in epidermis, the cleavage of collagen and the reduction or fragmentation of FN, elastin (ELN), and fibrillin (FBN), which is cross-linking, in the reticular dermis. Thinned epidermis is shown with a flattening of the rete pegs $[1,5,6]$. The reorganization of collagen, FN, ELN, and FBN are thought to be a key cause in SD pathogenesis, and these genes are used as genetic markers for SD [7,8].

In early stretch marks, mast cell degranulation and macrophage activation are also observed in the reticular dermis, and elastolysis of extracellular matrix (ECM) is promoted [9]. Obese woman with SD revealed the increase of mast cells around the vessels in the dermis, and fragmented and thinned ELN fibers [10]. Protease and cytokines referred to as mast cell mediators are a necessary source for the breakdown of FBN and ELN, as well as the activation of metalloproteinase [11-13]. These implicate that mast cell mediators including 
elastases be proposed as a key initiatory step in SD. However, mast cell activation on SD pathogenesis has not yet been fully studied.

Mast cells can respond to environmental, biochemical, physical, and mechanical stimuli. A general study of mast cell activation has focused on the aggregation of the high-affinity Fc epsilonR1 alpha (FceR1) receptor by antigen-binding immunoglobulin $\mathrm{E}$ (IgE) as a chemical stimulus [14]. Other studies have revealed that physical and mechanical stimuli also induce the activation of mast cell [15-17]. Bindings of cell surface receptors to adjacent ECMs function as physical and mechanical stimuli, and promote mast cell activation $[18,19]$. Integrin is a cell surface receptor composed of heterodimeric transmembrane glycoproteins containing $\alpha$ and $\beta$ subunits that bind to ECM proteins, such as FN, vitronectin, and fibrinogen containing an arginine-glycine-aspartic acid (RGD) sequence or connecting segment (CS)-1 peptide. In addition to functioning as mechanical anchors, integrin mediates the transmission of physical and mechanical stimuli into biochemical signals, which promotes the release of granules, protease, and inflammatory cytokines, leading to disruption of the ECM structure [20-25]. Physical and mechanical stimulation is one of the triggers for stretch marks. SD is caused by the rapid tissue expansion of weakened skin connective tissue [26,27]. Based on the evidence, we suggest that mast cell degranulation through the adhesion of integrin to FN could be a novel target for the treatment of SD. We first screened for substances that alleviate mast cell adhesion to FN and found that LIFE significantly inhibited mast cell adhesion to FN among various extracts.

Lagerstroemia indica (LI), family Lythraceae, is well known as Indian Crape myrtle. It is native to the Indian subcontinent, but it is distributed in many countries, including those of Southeast Asia, China, Korea, and Japan, due to its ease of cultivation. According to traditional Indian medical treatment, bark, leaves and flowers of LI are used as diuretic and fever remedy [28]. In addition, LI displays various biological properties that include anti-inflammatory, antipyretic, analgesic, anti-diabetic, antioxidant, and hepatoprotective activity [29-32]. However, the effects of LI and its molecular mechanism on SD have not yet been fully understood.

The purpose of this study is to evaluate LIFE as an inhibitor of mast cell activation and an activator of ECM component in fibroblast. We investigated the inhibitory effect of LIFE on FN-induced mast cell activation. Also, we tested the changes of ECM components in fibroblasts by mediators from activated mast cells and the recovery effect of LIFE on these alterations.

\section{Results}

\subsection{LIFE Inhibits Mast Cell Binding to FN}

RBL-2H3 cells are of mucosal mast cell origin, and they are a prime model for investigating immediate hypersensitivity reactions [33,34]. In addition, RBL-2H3 cells spontaneously adhere to FN, vitronectin, and fibrinogen, leading to activation of mast cells [22,35]. Following previous studies, we observed FN-induced mast cell activation using RBL-2H3 cells.

Cytotoxicity of LIFE on a rat mucosal mast cell line, RBL-2H3, was measured by a MTT assay that measures cell metabolic activity in the cell culture. LIFE extracts did not show cytotoxicity to RBL-2H3 at 50 and $100 \mu \mathrm{g} / \mathrm{mL}$ of LIFE (Figure 1A). Under the non-toxicological levels, we investigated the effect of LIFE on mast cell adhesion. 


\section{A}

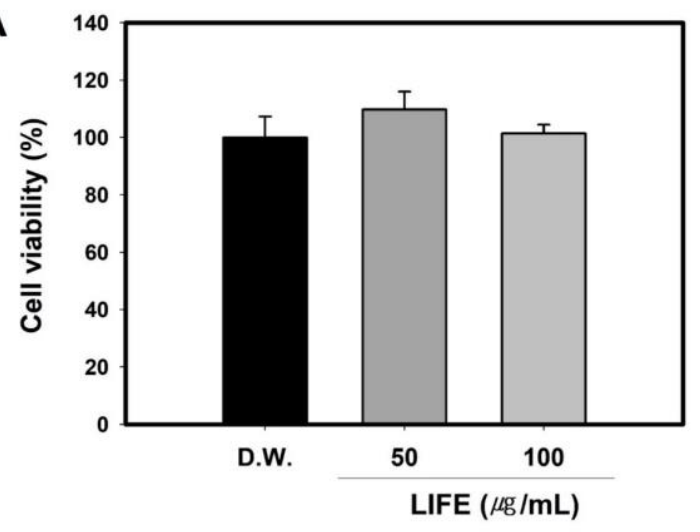

C

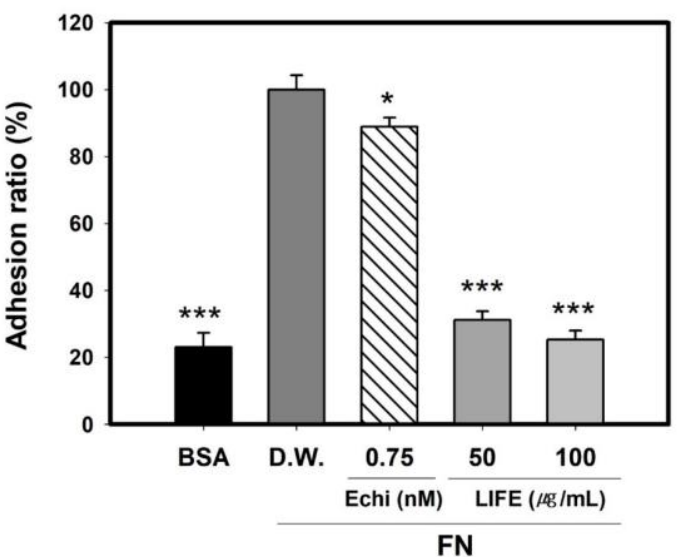

B
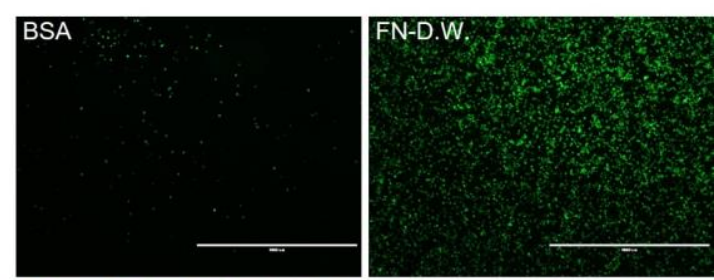

FN-Echi $0.75 \mathrm{nM}$

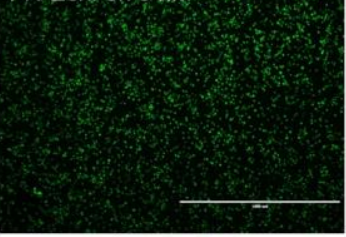

FN-LIFE $50 \mu \mathrm{g} / \mathrm{mL}$

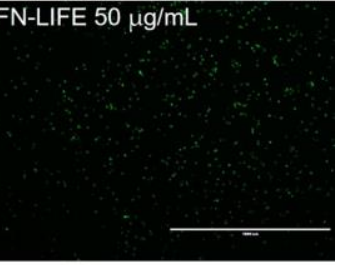

FN-LIFE $100 \mu \mathrm{g} / \mathrm{mL}$

Figure 1. LIFE decreases the binding of rat mucosal mast cell line RBL-2H3 to FN. Cells (passage $3-7$ ) at $90 \%$ confluence were pretreated with (50 or 100) $\mu \mathrm{g} / \mathrm{mL}$ of LIFE for $24 \mathrm{~h}$. (A) Cell viability of RBL-2H3 was measured by MTT assay. RBL-2H3 cells pretreated with LIFE were labelled by calcein-AM for $30 \mathrm{~min}$ at $37^{\circ} \mathrm{C}$, and then seeded onto FN-coated plates for $2 \mathrm{~h}$. (B) Fluorescence intensity was observed under fluorescence microscopy, and was determined using Infinite M200. (C). Data are presented as mean \pm SEM from three replicated measurements. One-way ANOVA followed by the post hoc Dunnett's multiple comparisons test $\left(n=3,{ }^{*} p<0.05,{ }^{* * *} p<0.001\right.$, compared with control-D.W. treated). Echi: echistatin, BSA: bovine serum albumin, FN-fibronectin, LIFE: Lagerstroemia indica flower extract.

As reported, RBL-2H3 cells adhered to FN without any stimuli, unlike its adherence to bovine serum albumin (BSA) (Figure 1B,C). To observe the effect of LIFE on the binding of mast cell to FN, we examined the adherence of RBL-2H3 pretreated by LIFE or echistatin (Echi), RGD inhibitor, as positive control, on the FN-coated plates. Echi hinders the interaction between integrin and ECM by competitively binding with integrin $\alpha \mathrm{v} \beta 3, \alpha \mathrm{II} \beta 3$, and $\alpha 5 \beta 1$ [36]. Figure $1 \mathrm{C}$ showed that the adhesion of RBL-2H3 to FN was significantly inhibited by (50 and 100) $\mu \mathrm{g} / \mathrm{mL}$ of LIFE up to about (70 and 80) \%, respectively. The adhesion of RBL-2H3 pretreated with Echi to FN was decreased by up to about $12 \%$ at $0.75 \mathrm{nM}$.These results suggest that LIFE could be an effective inhibitor for the adhesion of mast cell to FN.

\subsection{LIFE Decreases the Expression of Integrin $\alpha_{4}$ and $\beta_{3}$}

Multiple integrin $\alpha 3 \beta 1, \alpha 4 \beta 1, \alpha 5 \beta 1$, and $\alpha \mathrm{v} \beta 3$ are involved in the adhesion to RGD sequence of FN. Among them, $\alpha 4, \alpha 5$, and $\beta 3$ subunits play key roles in the adhesion to FN and the activation of RBL-2H3 cells [22].

To reveal its mechanism of LIFE on the adhesion to FN, we measured the expression of integrin $\alpha 4, \alpha 5$, and $\beta 3$ using cells pretreated with LIFE. Figure $2 \mathrm{~A}$ shows that the 
expression of integrin $\alpha 4$ was decreased by LIFE at (50 and 100) $\mu \mathrm{g} / \mathrm{mL}$ by $\sim(30$ and 50) \%, respectively, compared to control group. The expression of integrin $\alpha 5$ and $\beta 3$ was not significantly altered by LIFE.
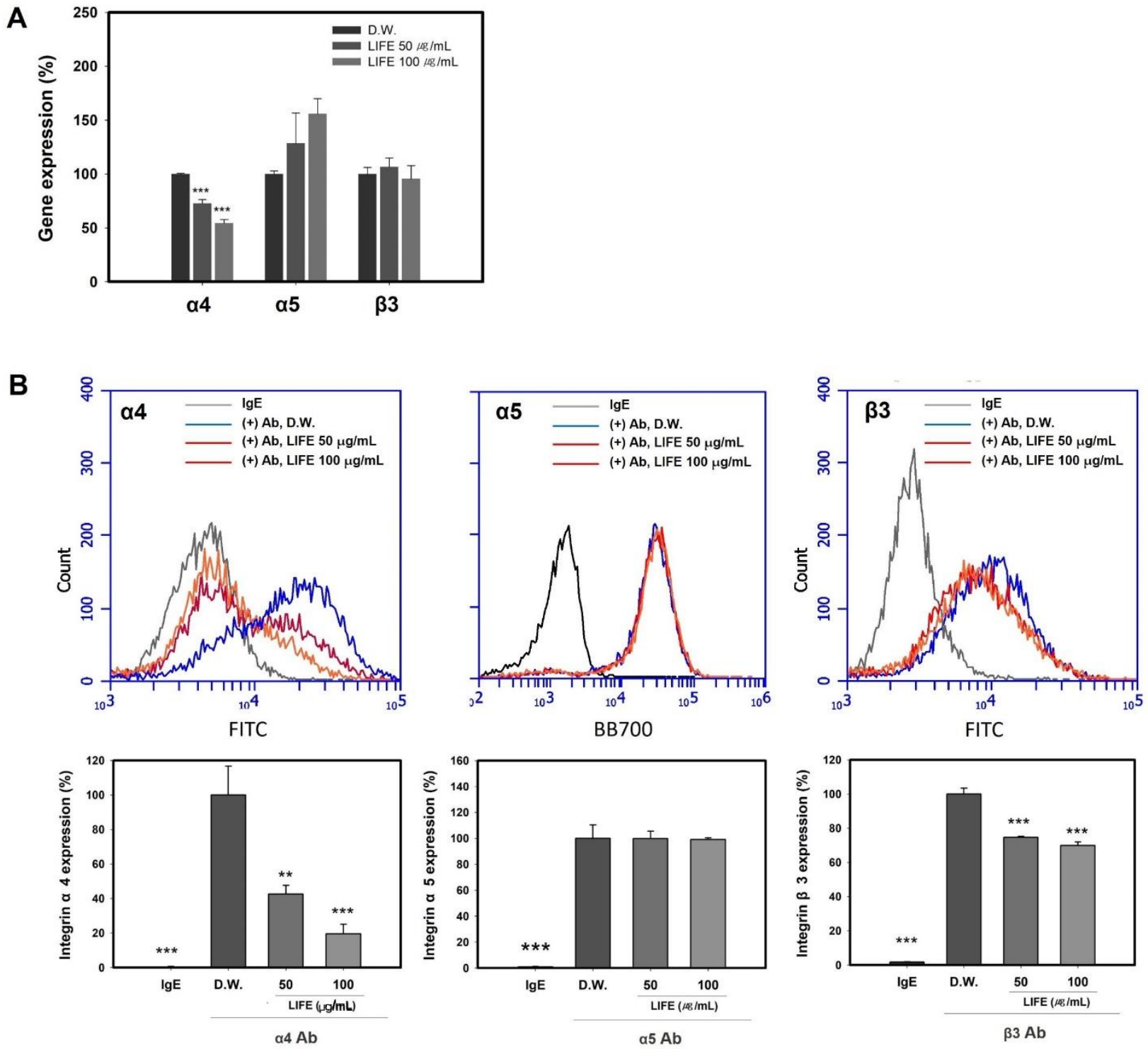

Figure 2. LIFE downregulates the expression of integrin $\alpha_{4}$ and $\beta_{3}$ in RBL-2H3. Cells (passage 3-7) at $90 \%$ confluence were pretreated with $(50$ or 100$) \mu \mathrm{g} / \mathrm{mL}$ of LIFE for $24 \mathrm{~h}$. (A) Integrin $\alpha 4, \alpha 5$, and $\beta 3$ mRNA were measured by quantitative real-time PCR. (B) Integrin $\alpha 4, \alpha 5$, and $\beta 3$ on the surface of RBL-2H3 cells were measured by flow cytometry. Cells were harvested, and stained with antibodies for specific integrins on the surface of the cell. Data are presented as mean \pm SEM from three replicated measurements. One-way ANOVA followed by the post hoc Dunnett's multiple comparisons test $\left(n=3,{ }^{* *} p<0.01,{ }^{* * *} p<0.001\right.$, compared with control-D.W. treated). Ab: Antibody, IgE: immunoglobulin E, LIFE: Lagerstroemia indica flower extract.

We next confirmed the number of integrins on the cell surface by using antibodies to integrins $\alpha 4, \alpha 5$, and $\beta 3$ in flow cytometry. Figure $2 \mathrm{~B}$ shows that LIFE at $100 \mu \mathrm{g} / \mathrm{mL}$ effectively reduced the number of integrin $\alpha 4$ by up to $\sim 80 \%$, consistent with the mRNA expression results. The expression of integrin $\beta 3$ on cell surface was inhibited by LIFE at $100 \mu \mathrm{g} / \mathrm{mL}$ by up to $\sim 30 \%$. The expression of integrin $\alpha 5$ was not significantly changed by LIFE at 50 and $100 \mu \mathrm{g} / \mathrm{mL}$. These results suggest that the inhibition of binding mast cell 
to FN by LIFE is regulated by the reduction of integrins $\alpha 4$ and $\beta 3$, rather than $\alpha 5$, on the cell surface.

\subsection{LIFE Inhibits FAK Phosphorylation but Not Intact FAK Protein}

Integrin is a sensory molecule that converts mechanical information from the ECM into biochemical signals. The binding with FN promotes the clustering of integrins, which recruit signaling proteins to form a clustered adhesion complex, leading to the phosphorylation of signaling proteins like FAK [37-39]. From these references, we hypothesized that the reduction of integrins by LIFE could decrease the phosphorylation of FAK.

Next, we tested whether LIFE changes the status of FAK phosphorylation. Following the procedure of the adhesion experiments (Figure 1B), RBL-2H3 cells pretreated with LIFE at $50 \mu \mathrm{g} / \mathrm{mL}$ for $24 \mathrm{~h}$ were seeded onto the FN-coated plates, and harvested every $30 \mathrm{~min}$ for up to $2 \mathrm{~h}$. Figure 3 shows that the increase of phosphorylated FAK along with the adhesion time was inhibited by LIFE at $50 \mu \mathrm{g} / \mathrm{mL}$, whereas the amount of FAK intact protein was not affected. The results suggest that the decrease of integrins by LIFE results in the inhibition of FAK phosphorylation, as well as the reduction of adhesion to FN.

\section{D.W. LIFE $50 \mu \mathrm{g} / \mathrm{mL}$}

\section{$\begin{array}{llllllllll}0 & 15 \mathrm{~m} & 30 \mathrm{~m} \quad 1 \mathrm{~h} & 2 \mathrm{~h} & 0 & 15 \mathrm{~m} & 30 \mathrm{~m} & 1 \mathrm{~h} & 2 \mathrm{~h}\end{array}$}

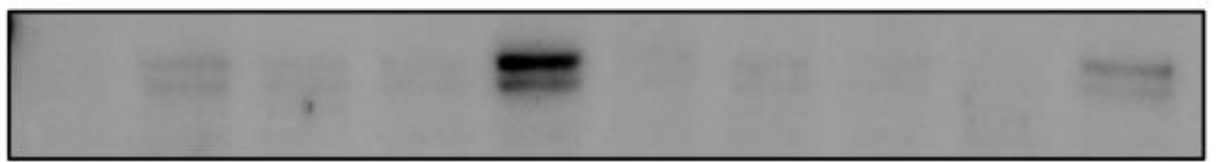

FAK

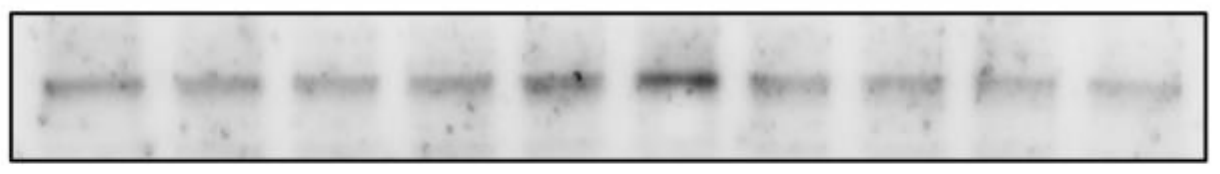

ACT

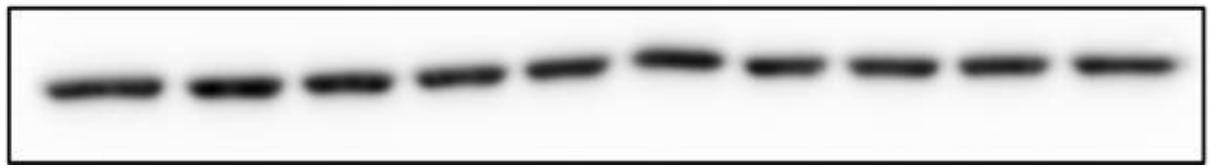

Figure 3. LIFE decreases FAK phosphorylation, but not intact FAK protein. Cells (passage 3-7) at $90 \%$ confluence were pretreated with $50 \mu \mathrm{g} / \mathrm{mL}$ of LIFE for $24 \mathrm{~h}$. Cells were seeded onto FN-coated plates for $2 \mathrm{~h}$, harvested at the indicated time, and then, analyzed by Western blot analysis with anti-Pfak(Y397), anti-FAK, and anti-Actin. FAK: focal adhesion kinase, ACT: actin, LIFE: Lagerstroemia indica flower extract.

\subsection{LIFE Decrease the IgE-Induced Relases of Graunles and Cytokine IL-3 on FN-Coated Plate}

Adhesion to the ECM synergistically promotes mast cell activation, along with FceR1. Degranulation of RBL-2H3 in response to aggregation of the high-affinity FceR1 receptor by antigen-bound IgE was significantly promoted on FN-coated plates. IgE-induced mast cell degranulation on FN was reversible by RGD and CS-1 peptides, or by integrin antibodies [21,22,35]. This means that interaction between integrin and FN promotes IgE-induced mast cell degranulation.

To determine the inhibitory effect of LIFE on the IgE-induced degranulation on FN, we measured the degranulation ratio using the activated mast cells on FN-coated plate. For activation, RBL-2H3 cells pretreated with LIFE for $24 \mathrm{~h}$ were sensitized with IgE for $2 \mathrm{~h}$, and then adhered to FN while triggering the cells with 2,4-dinitrophenylated BSA (DNP-BSA). After stimulation and adhesion for $2 \mathrm{~h}$, the degranulation ratio was measured by the activity of $\beta$-hexosaminidase, a granule enzyme. Figure $4 \mathrm{~A}$ shows that the degranulation ratio was inhibited by LIFE at $100 \mu \mathrm{g} / \mathrm{mL}$ by up to $\sim 30 \%$. 
In addition, we examined the inhibitory effect of LIFE on the release of IL-3 known as inflammatory cytokines to response to FN [20]. IL-3 levels in supernatants from $24 \mathrm{~h}$ stimulated mast cells were analyzed using enzyme-linked immunosorbent assay (ELISA). Figure 4B shows that LIFE significantly inhibited the release of IL-3 at $100 \mu \mathrm{g} / \mathrm{mL}$ by up to $\sim 86 \%$. These results demonstrate that LIFE decreased IgE-induced degranulation and cytokine IL-3 on an FN-coated plate through the inhibition of the adhesion to FN.
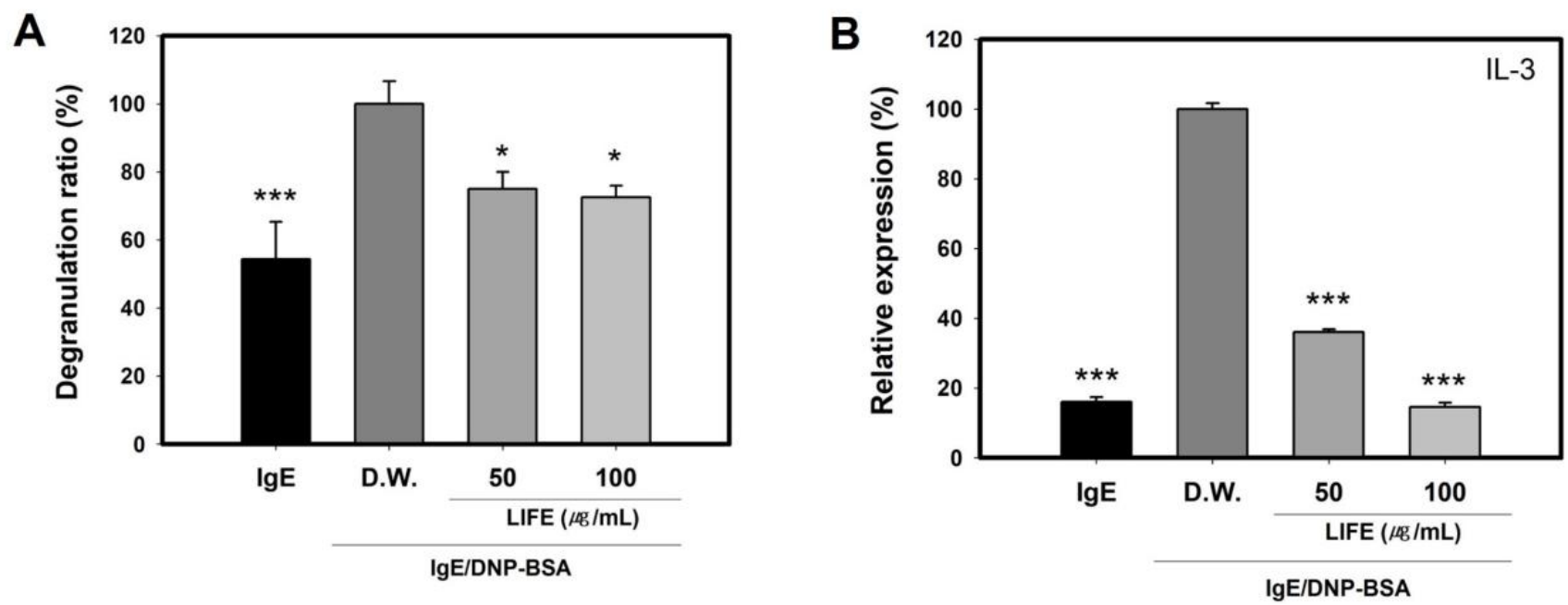

Figure 4. LIFE downregulates IgE-induced degranulation and release of cytokines from RBL-2H3 on FN-coated plate. Cells pretreated by (50 or 100) $\mu \mathrm{g} / \mathrm{mL}$ LIFE for $24 \mathrm{~h}$ were sensitized by $1 \mu \mathrm{g} / \mathrm{mL}$ of IgE for $2 \mathrm{~h}$, and then cells were seeded onto FN-coated plates with $25 \mathrm{ng} / \mathrm{mL}$ of DNP-BSA for $2 \mathrm{~h}$. (A) The degranulation ratio was calculated by measuring the activity of $\beta$-hexosaminidase in supernatant and lysate. (B) IL-3 levels were measured by ELISA. Data are presented as mean \pm SEM from three replicated measurements. One-way ANOVA followed by the post hoc Dunnett's multiple comparisons test $\left(n=3,{ }^{*} p<0.05,{ }^{* * *} p<0.001\right.$, compared with control-D.W. treated group). IgE: immunoglobulin E, DNP-BSA: 2,4-dinitrophenylated BSA.

2.5. Conditioned Medium from Activated RBL-2H3 Changes the Expression of ECM Components and Inflammatory Mediators in Fibroblast

In the early SD, mast cell activation in the mid dermis promotes the destruction of the ECM component. However, the relationship between mast cell activation and dermal fibroblasts in the regulation of ECM component known as genetic markers for SD has been little studied. We observed whether mediators released from activated mast cells can influence the synthesis of ECM components in fibroblasts.

We first examined the effect on normal human dermal fibroblasts (NHDFs) of treating conditioned medium (CM) from RBL-2H3 in response to antigen-bound IgE. A previous report found that the genes related to the decomposition of ECM and pro-inflammation were changed in the HDF isolated from a SD lesion [8]. Figure 5 shows that consistent with this, we found that most ECM components were decreased in the NHDF treated with the CM from RBL-2H3 in response to antigen-bound IgE, when compared to non-treated NHDF. The collagens type I (COL1) and III (COL3) were decreased by (45 and 80) \%, respectively. FN and ELN were also reduced by (78 and 80) \%, respectively. Also, biglycan (BGN) and lumican (LUM), which are necessary for the assembly of collagen fibrils, were decreased by (59 and 33) \%, respectively. In our condition, lysyl oxidase (LOX) and FBN4 were not changed, although FBN1 was decreased by $64 \%$. In the same condition, we found a marked difference on matrix metallopeptidase 1(MMP1). Its expression was strongly increased by $607 \%$, while a mild increase was observed on the expression of MMP3 (37\% of control). In addition, we found a significant increase of an inflammatory mediator, C-X-C motif chemokine ligand 8 (CXCL8) (1400\% of control), but not tumor necrosis factor- $\alpha$ (TNF- $\alpha)$. 
On the other hand, previous reports showed that cluster of differentiation 26 (CD26), a known marker of fibrogenic fibroblast, is upregulated, while in contrast, cluster of differentiation 74 (CD74), a known anti-fibrotic surface receptor, is downregulated in early SD lesion [40]. Also, the increase of alpha-smooth muscle actin ( $\alpha$-SMA) is thought to be a hallmark of early SD, distinguishing from late SD [27]. Unlike previous reports, the CM of mast cells in our condition did not cause any differences in $\alpha$-SMA and CD-26 expression, but increased the expression of CD74. In agreement, transforming growth factor- $\beta$ (TGF- $\beta 1$ ), an inducer of collagen synthesis, and vascular endothelial growth factor A (VEGF-A), a stimulator of collagen deposition, showed no significant differences between treatment and non-treatment with CM from RBL-2H3 cells.

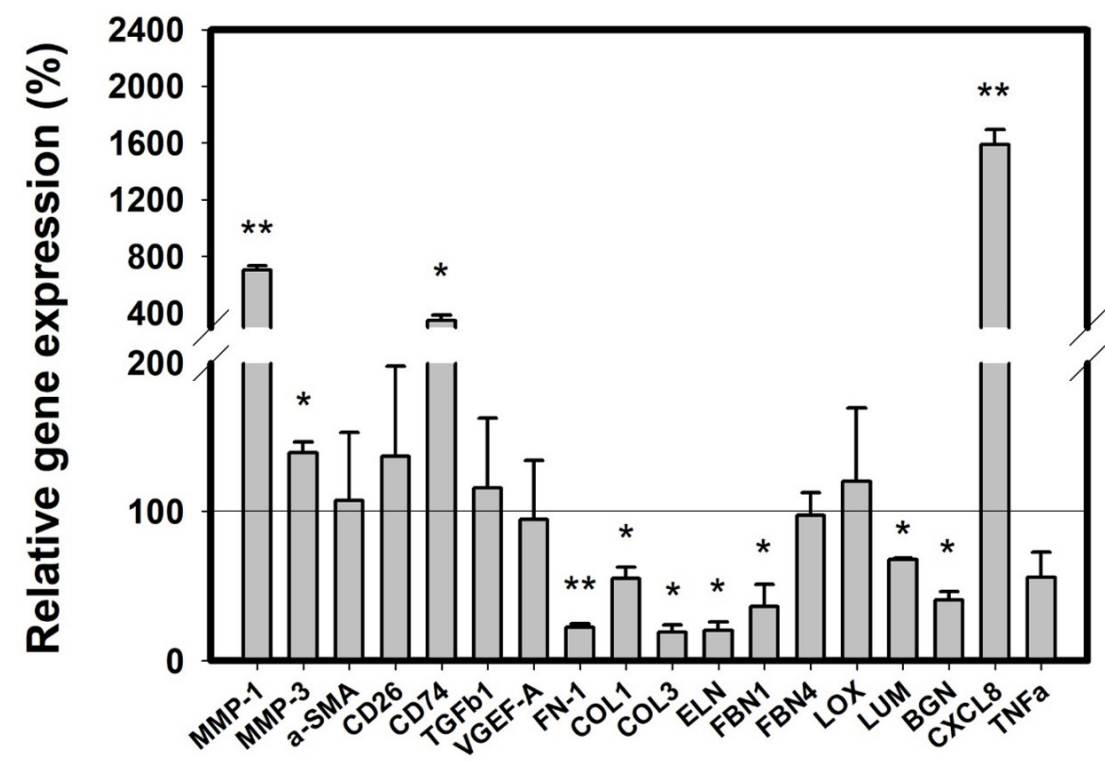

Figure 5. Conditioned medium from RBL-2H3 increases the expression of ECM components and inflammation mediator in NHDF. RBL-2H3 cells (passage 3-7) at 90\% confluence was sensitized with $200 \mathrm{ng} / \mathrm{mL}$ of IgE for $24 \mathrm{~h}$. Then, cells were activated with $100 \mathrm{ng} / \mathrm{mL}$ of DNP-BSA for $2 \mathrm{~h}$. CM was collected from activated RBL-2H3 cells, and 50\% CM or DMEM were treated onto NHDF for $24 \mathrm{~h}$. The gene expression was measured by quantitative real-time PCR. Data are shown as relative value compared with $\mathrm{CM}$ non-treated control (line). Data are presented as mean $\pm \mathrm{SEM}$ from three replicated measurements. Student's $t$-test $\left(n=3,{ }^{*} p<0.05,{ }^{* *} p<0.01\right.$, compared with CM non-treated control).

These results demonstrated that CM from RBL-2H3 in response to IgE increases the expression of ECM components and inflammatory mediator, like that shown in HDF isolated from an SD lesion.

\subsection{LIFE Restores Abnormal Genes Expression in Fibroblast in Response to the Conditioned Medium from the Activated Mast Cells}

Based on these results, we next wondered if LIFE could restore abnormal expressions of genes involved in the decomposition of ECM and pro-inflammation induced by CM from RBL-2H3. As shown in Figure 6A, we observed that LIFE enhanced COL1, COL3, FN1, ELN, and BGN expression in dose-dependent manner, but not FBN1 and LUM. Also, MMP-1, MMP-3, and CXCL8 expressions were downregulated by LIFE at $(25,50$, or 100$) \mu \mathrm{g} / \mathrm{mL}$ in dose-dependent manner (Figure 6B). These results demonstrate that LIFE was essential for alleviating the abnormal expressions of genes involved in SD. 
A

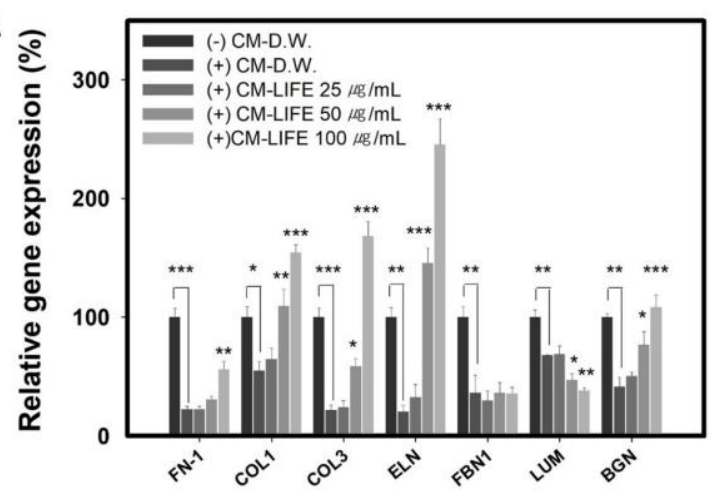

B

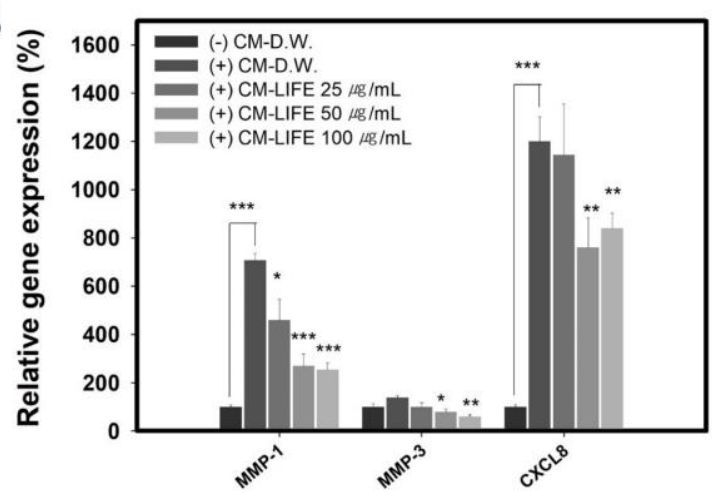

Figure 6. LIFE restores abnormal genes expression in NHDF in response to the conditioned medium from the activated RBL-2H3. CM of activated RBL-2H3 cells was obtained under the same conditions as in Figure 6. Fifty percent CM or DMEM was treated with $(25,50$, or 100$) \mu \mathrm{g} / \mathrm{mL}$ LIFE in NHDF. $(\mathbf{A}, \mathbf{B})$ The expression of genes was measured by quantitative real-time PCR. Data are shown as relative value compared with $\mathrm{CM}$ non-treated control. Data are presented as mean \pm SEM from three replicated measurements One-way ANOVA followed by the post hoc Dunnett's multiple comparisons test $\left(n=3,{ }^{*} p<0.05,{ }^{* *} p<0.01{ }^{* * *} p<0.001\right.$, compared with (+) CM-D.W. treated group).

\subsection{Phenolic Compounds Analysis of LIFE}

To identify the chemical composition of LIFE, we analyzed the phenolic compounds in LIFE by HPLC. The LIFE mainly contained $19.0 \mathrm{mg}$ ellagic acid equivalent/g dried extract. Figure 7 shows that the major peak, $\mathrm{tR}$ of $23.8 \mathrm{~min}$, was identified as ellagic acid. Its content was calculated as over $(1.90 \pm 0.87) \%(w / w)$. Other phenolic compounds such as gallic acid, catechin, luteolin, quercetin, apigenin and kaempferol were not detected in LIFE.

A

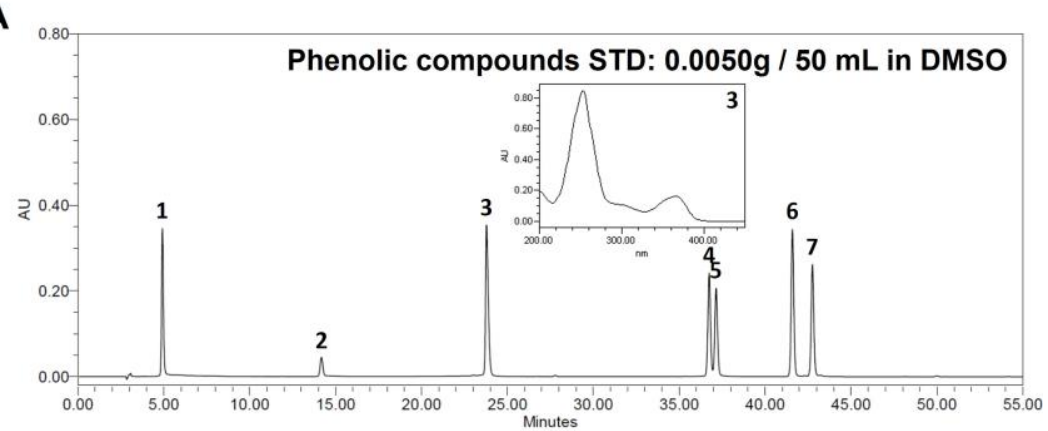

B

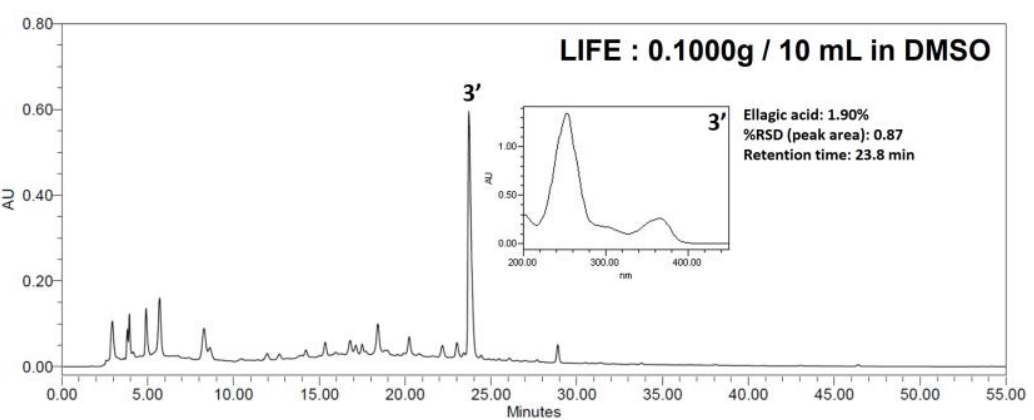

Figure 7. Composition of LIFE extracts. HPLC chromatogram of LIFE at $270 \mathrm{~nm}$. (A) HPLC chromatogram of standard (STD) at $270 \mathrm{~nm}$. 1-Gallic acid; 2-Catechin; 3-Ellagic acid; 4-Luteolin; 5-Quercetin; 6-Apigenin; 7-Kaempferol (B) HPLC chromatogram of LIFE at $270 \mathrm{~nm}$. Contents values are presented as mean \pm SEM from three replicated measurements. STD: standard, DMSO: dimethyl sulfoxide. 


\subsection{Ellagic Acid Inhibits Mast Cell Binding to FN}

To clarify the roles of ellagic acid, the inhibitory effect on mast cell adhesion was evaluated. Under the non-toxicological levels (Figure 8A), we tested the binding of RBL$2 \mathrm{H} 3$ cells pretreated with ellagic acid (EA) on FN. Figure $8 \mathrm{C}$ showed that the adhesion ratio of RBL-2H3 cells pretreated with ellagic acid to FN was decreased by up to $\sim 70 \%$ at $200 \mu \mathrm{M}$. These results suggest that EA is one of the active ingredients contributing to the inhibitory effect on mast cell adhesion of LIFE (Figure 8B,C).

A

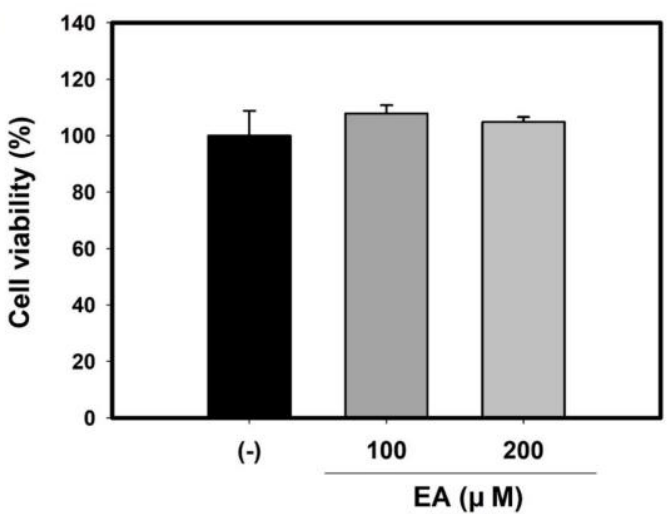

B

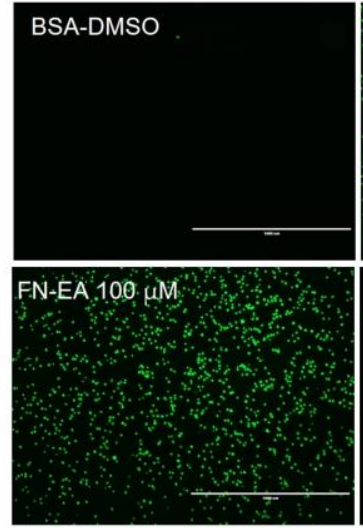

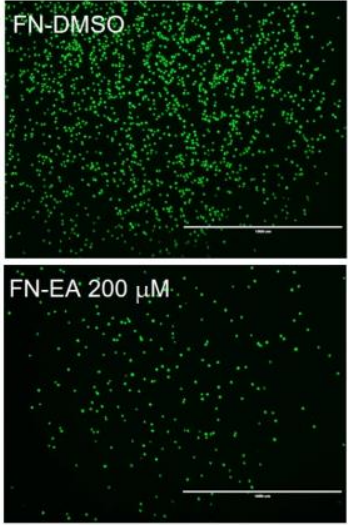

C

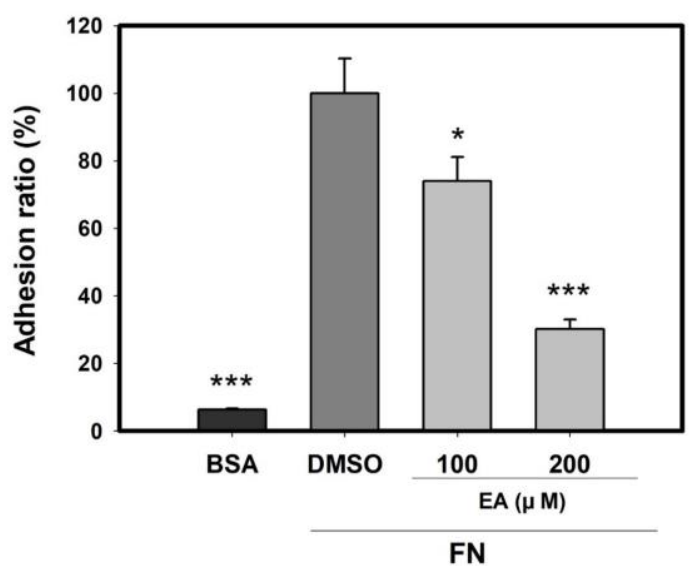

Figure 8. Ellagic acid inhibits the binding of RBL-2H3 to FN. Following the procedure in Figure 1, cells were pretreated with (100 or 200) $\mu \mathrm{M}$ ellagic acid for $24 \mathrm{~h}$. (A) Cell viability of RBL-2H3 was measured by MTT assay. Cells labelled by calcein-AM were seeded onto FN-coated plates for $2 \mathrm{~h}$. (B) The fluorescence intensity was observed under fluorescence microscopy, and (C) was determined using Infinite M200. Data are presented as mean \pm SEM from three replicated measurements. One-way ANOVA followed by the post hoc Dunnett's multiple comparisons test $(n=3, * p<0.05$, *** $p<0.001$ compared with control-DMSO treated). EA: ellagic acid, BSA: bovine serum albumin, FN: fibronectin, DMSO: dimethyl sulfoxide.

\section{Discussion}

LIFE inhibits the adhesion of RBL-2H3 on FN and decreases the expression of integrin, thereby leading to reduced FAK phosphorylation. Through the inhibition of the adhesion to FN, LIFE decreases IgE-induced degranulation on FN-coated plate. Although further experiments are needed, based on these results, we suggest that LIFE can be a novel agent for relieving stretch marks.

Mechanical stretching during rapid tissue expansion is one cause of the SD pathogenesis, owing to the perpendicularity of SD to the direction of skin [26]. Skin reveals various physiological and cellular responses to mechanical stress. Mechanical stimuli can be converted to biochemical responses through various cellular molecules, which include mechanosensitive ion channels, G-protein coupled receptors, protein kinases, integrin- 
matrix interactions, and other membrane-associated signal-transduction molecules [41] Especially, it is well-known that interaction between integrin and ECM senses mechanical stress, and then activates intracellular pathway [42,43]. In the case of mast cell, mechanical stretching induces mast cell degranulation by the adhesion of integrin and FN [23]. These facts can provide an infinite link between integrin-FN interaction and mast cell degranulation, which is known as an early event in the pathogenesis of SD. Although further genetic experiments are needed, one possible pathogenic mechanism of SD is apparent: mechanical stress during tissue expansion induces mast cell degranulation through the adhesion of integrins to ECM, and subsequently promotes elastolysis. Based on this hypothesis, we suggest that the integrin-FN interaction-induced mast cell degranulation can be a new in vitro evaluation to screen for agents alleviating SD.

Some reports suggest that CD26 and $\alpha$-SMA, known as fibrotic markers, increase in early lesions of SD $[27,40]$. However, we observed that CM of mast cells did not influence the expression of $\alpha$-SMA and CD-26, but slightly increased the expression of CD74 known as an anti-fibrotic marker in fibroblast (Figure 6). In the relationship between mast cells and fibroblasts, many studies have addressed the pro-fibrotic or anti-fibrotic role of MCs in models of fibrosis, with partially conflicting results. Because this seems particularly relevant to the degree of stimuli given, results can change, depending on the experimental design [44]. From the aspect of the anti-fibrotic role, evidence is also prominent; extensive elastosis in sun-exposed skin was related to the increased mast cell prevalence or CM of mast cells, which reduces collagen and provokes pro-inflammatory signal in human tenocytes $[45,46]$. Despite controversy over the role of mast cells, our data showed that mediators from activated mast cells increases the expression of ECM components and inflammatory cytokine, like that shown in HDF isolated from an SD lesion. Therefore, we suggest that in vitro evaluation using the CM obtained from activated mast cells will be a good tool to screen for cosmetic agents for the treatment of SD.

In our study, we found that LIFE contains a higher proportion of EA (Figure 7). EA is a natural polyphenolic compound with strong antioxidant and anti-proliferative properties that is found in many fruits, seeds, and vegetables. The results from recent research have shown that EA has anti-proliferative, anti-atherogenic, anti-inflammatory, neuroprotective, and anti-carcinogenic effects. In anti-inflammatory activity, EA inhibits the binding and recruitment of circulating monocytes to vascular endothelial cells by decreasing the expression of adhesion molecules $[47,48]$. In addition, EA attenuates IgEmediated allergic response in mast cells [49]. In the present study, EA inhibits the adhesion of mast cells to FN. There is the possibility that ellagic acid is an active compound of LIFE for inhibitory effect on FN-induced mast cell activation, although further study is needed.

In order to become an inhibitory active compound in LIFE, EA needs to show efficacy at a concentration of $0.95 \mu \mathrm{g} / \mathrm{mL}(1.9 \%$ in extract). However, we observed that EA showed inhibitory efficacy at a concentration of $100 \mu \mathrm{M}(\approx 30 \mu \mathrm{g} / \mathrm{mL})$ (Figure 8). Previous studies have shown that, in addition to EA, LI also contains various phenolic compounds, including 3-O-methyl gallate, isovitexin, vitexin, orientin, pyrogallol, and vanillic acid $[29,31]$. Therefore, we suggest that there are other active compounds with superior inhibitory activity than EA or show synergistic effects with EA. To identify the active compound inhibitory activity on mast cell adhesion, we are currently in the process of bioactivity-guided fractionation.

\section{Materials and Method}

\subsection{Preparation of LIF Extracts}

LIFE was obtained from the Jeonglim Agricultural Association (Namwon, South Korea). Water extract of LIFE was prepared by reflux extraction in purified water at (90-95) ${ }^{\circ} \mathrm{C}$ for $3 \mathrm{~h}$. The extracts were filtered through filter paper. After spray drying, a perfectly dried LIFE was obtained. The obtained extract was dissolved in distilled water for further experiments. 


\subsection{Cell Culture and Cell Treatment}

Rat mucosal mast cell line (RBL-2H3; CRL-2256 ${ }^{\mathrm{TM}}$, ATCC, Manassas, VA, USA) was maintained in ATCC-formulated Eagle's minimum essential medium (30-2003, ATCC) supplemented with $15 \%$ fetal calf serum and $1 \%$ penicillin/streptomycin (Gibco). Normal human dermal fibroblast (NHDF; PCS-201-012 ${ }^{\mathrm{TM}}$, ATCC, Manassas, VA, USA) were maintained in Dulbecco's modified Eagle's medium (Welgene, Daegu, Korea) supplemented with $10 \%$ fetal calf serum and $1 \%$ penicillin/streptomycin (Gibco). Cells were maintained at $37{ }^{\circ} \mathrm{C}$, under $5 \% \mathrm{CO}_{2}$.

For treatment with LIFE, echistatin (3202, R\&D system), and ellagic acid (5070, ChromaDex $^{\mathrm{TM}}$ ), RBL-2H3 cells (passage 3-7) at 90\% confluence were treated with substances for $24 \mathrm{~h}$.

\subsection{Adhesion Assay}

The method was based on Lam et al., and modified [50]. RBL-2H3 cells were washed with $0.1 \%$ BSA + EMEM, resuspended at $1 \times 10^{6}$ cells $/ \mathrm{mL}$, and labeled with $3 \mu \mathrm{g} / \mathrm{mL}$ of Calcein-AM (17783, Merck, Darmstadt, Germany) for $30 \mathrm{~min}$ at $37^{\circ} \mathrm{C}$. After labeling, cells were washed three times, and resuspended at $1 \times 10^{6}$ cells $/ \mathrm{mL}$ in $0.1 \%$ BSA + EMEM. The $100 \mu \mathrm{L}$ of cell mixture was seeded onto an FN-coated 96-well plate (CWP001, R\&D systems) and incubated at $37^{\circ} \mathrm{C}$. After $1 \mathrm{~h}$, the fluorescence of total cells was measured with Infinite M200, washed with $0.1 \%$ BSA + EMEM three times, and then the remaining cells were measured. The degree of adhesion is expressed as the percentage of fluorescence remaining in the wells, after washing away unbound cells.

\section{4. $\beta$-Hexosaminidase Release Assay}

The method was based on John et al., and modified [24,35]. RBL-2H3 cells were resuspended in complete EMEM medium at a concentration of $3 \times 10^{6}$ cells $/ \mathrm{mL}$, and were incubated with $1 \mu \mathrm{g} / \mathrm{mL}$ of $\operatorname{IgE}-\mathrm{DNP}$ (D8406, Sigma) for $2 \mathrm{~h}$ at $37^{\circ} \mathrm{C}$. The cells were then washed three times, and resuspended in HBSS containing $1.5 \mathrm{mM}$ of $\mathrm{CaCl}_{2}$ and $0.2 \% \mathrm{BSA}$. Next, cells were seeded to FN-coated 24-well plates, and allowed to adhere with $25 \mathrm{ng} / \mathrm{mL}$ DNP-BSA (324101, Sigma) for $2 \mathrm{~h}$. The FN-coated 24-well plates were made as reference. The 24-well non-treated plates (32024, SPL) were coated with $50 \mu \mathrm{g} / \mathrm{mL}$ human FN (f1141, Sigma) in phosphate-buffered saline (PBS) for $16 \mathrm{~h}$ at $4{ }^{\circ} \mathrm{C}$, washed three times with PBS, blocked with $3 \%$ bovine serum albumin (BSA; a9418, Sigma) in HBSS (Hanks balanced salt solution-modified; $14025-092$, Gibco) for $1 \mathrm{~h}$ at $37^{\circ} \mathrm{C}$, then washed 3 times with PBS. The degranulation ratio of the activity of $\beta$-hexosaminidase in the culture supernatants was measured.

\subsection{Enzyme-Linked Immunosorbent Assay}

Cells were stimulated with IgE-DNP and DNP-BSA, following the method of the $\beta$-hexosaminidase release assay. For ELISA assay, cells were allowed to adhere for $24 \mathrm{~h}$. Supernatant obtained at the indicated time was analyzed by IL-3 (ab277709, abcam) ELISA kit, following the manufacturer's instructions.

\subsection{RNA Isolation and Quantitative Real-Time RT-PCR}

Total RNA was extracted using the Qiagen RNeasy Mini Kit (Qiagen, Hilden, Germany), following the manufacturer's instructions. Complementary DNA was obtained by the reverse transcription of $1 \mu \mathrm{g}$ of total mRNA using amfiRivert cDNA synthesis platinum master mix (GenDEPOT, Katy, TX, USA), following the manufacturer's instructions. Realtime reverse transcription PCR was done using an ABI PRISM 7500 (Applied Biosystems, Waltham, MA, USA), following the manufacturer's instructions. Table 1 lists the primer sequences. The primer sequences of all genes used in Figures 5 and 6 followed the method of Perez-Aso et al. [8]. 
Table 1. List of primer sequences.

\begin{tabular}{ccc}
\hline Gene Name & Accession Number & Primer Sequence \\
\hline \multirow{2}{*}{ Integrin $\alpha 4$} & NM_001107737.1 & F: ctcccacaggcctttattt \\
& & R: tctctgtcacgtcgcagttt \\
Integrin $\alpha 5$ & NM_001108118.1 & F: agctgcattccgagtctg \\
& R: ctcacactgaaggctgaacg \\
Integrin $\beta 3$ & NM_153720.1 & F: cacctgcatgtccaccaa \\
& & R: cagctgccacactcacagtt \\
\hline
\end{tabular}

\subsection{Flow Cytometry Analysis}

Cells were incubated with FITC-conjugated anti-CD49d $(\alpha 4)(557457, \mathrm{BD})$ and antiCD61( $\beta 3)(561909, \mathrm{BD})$ and BB700-conjugated anti-CD49e( $\alpha 5)(745884, \mathrm{BD})$. FITC-conjugated mouse IgG2a (553456, BD), FITC-conjugated mouse IgG1 (550616, BD), and BB700 hamster IgG1 were used as negative control, respectively. The detailed method was followed in accordance with the manufacturer's instructions. Cells were analyzed with an EVOS ${ }^{\circledR} \mathrm{FL}$ Cell Imaging System (Thermo Fisher Scientific, Waltham, MA, USA) and a BD Accuri ${ }^{\mathrm{TM}}$ C6 Plus (BD Biosciences, Franklin Lakes, NJ, USA).

\subsection{Western Blotting}

Cell lysates were prepared with protein extraction reagent (71009-3, Novagen) with protease inhibitor and phosphatase inhibitor (P3100, P3200, GenDEPOT). Total proteins were separated by a NuPAGE electrophoresis system (Thermo Fisher Scientific, Waltham, MA, USA) and transferred to polyvinylidene difluoride (PVDF) membranes. Immunoblotting was performed using primary antibody against pFAK(Y327) (3283, Cell Signaling Technology, Danvers, MA, USA), FAK (AF4467, R\&D system) and $\beta$-actin (Santa Cruz Biotechnology, Inc., Dallas, TX, USA). Scanning densitometric values of bands were analyzed using ImageJ, software version 1.52a (National Institutes of Health, Bethesda, MD, USA).

\subsection{Preparation of Activated Mast Cell-CM and Cell Treatment}

RBL-2H3 cells were cultured until reaching $90 \%$ confluence. For stimulation, cells were incubated with $200 \mathrm{ng} / \mathrm{mL}$ of IgE in $2 \% \mathrm{FBS}+\mathrm{EMEM}$, washed three times with PBS, and $100 \mathrm{ng} / \mathrm{mL}$ of DNP-BSA added in 2\% FBS + EMEM for $2 \mathrm{~h}$. The conditioned medium was collected, centrifuged at 10,000 rpm for $10 \mathrm{~min}$, and filtered through a $0.22-\mu \mathrm{m}$ syringe filter. Supernatants were collected and stored at $-80{ }^{\circ} \mathrm{C}$. The $50 \% \mathrm{CM}$ or DMEM were treated on NHDF for $24 \mathrm{~h}$.

\subsection{High-Performance Liquid Chromatography (HPLC)}

Identification and quantification of phenolic compounds in the LIFE were performed using Waters HPLC system (Waters, Milford, MA, USA) composed of Waters 2695 Separation module and Waters 996 PDA. A Phenomenex Luna C18 column $(4.6 \mathrm{~mm} \times 250 \mathrm{~mm}$, ID $5 \mu \mathrm{m}$ ) was used for separation. The sample injection volume was $10 \mu \mathrm{L}$. The signal was monitored at $270 \mathrm{~nm}$. Elution gradient: $10 \%$ organic phase B, hold for $5 \mathrm{~min}$; from 10 to $30 \%$ organic phase B in 25 min (linear gradient); from 30 to $50 \%$ organic phase B in 20 min (linear gradient); from 50 to $100 \%$ organic phase B in 10 min (linear gradient); $100 \%$ organic phase $\mathrm{B}$, hold for $10 \mathrm{~min}$; then back to the starting condition in $1 \mathrm{~min}$ and re-equilibration for $9 \mathrm{~min}$. The flow rate was $1.0 \mathrm{~mL} / \mathrm{min}$. Each analysis required $80 \mathrm{~min}$, including the re-equilibration time.

\subsection{Statistical Analysis}

Data were presented as mean \pm SEM from three replicated measurements and analyzed by Student's $t$-test or one-way ANOVA followed by the post hoc Dunnett's multiple comparisons test between two groups or among multiple groups. $p<0.05$ was considered statistically significant. 


\section{Conclusions}

LIFE inhibits FN-induced mast cell activation through the regulation of integrin expression. In addition, LIFE restores the alteration of ECM-related or inflammatory genes by mediators from activated mast cells. These results suggest that LIFE can be a novel natural plant source for relieving stretch marks.

Author Contributions: M.Y. and E.J. conceived and designed the experiments. M.Y., J.S., H.J., D.-H.R. and E.C. performed the experiments. M.Y., E.J. and D.P. analyzed and interpreted the data. M.Y. wrote the paper, and E.J. corrected the paper. All authors have read and agreed to the published version of the manuscript.

Funding: This research received no external funding.

Institutional Review Board Statement: Not applicable.

Informed Consent Statement: Not applicable.

Data Availability Statement: Data will be made available on request.

Conflicts of Interest: The authors declare no conflict of interest.

Sample Availability: Not available.

List of Abbreviations

Abbreviations

DNP-BSA

ACT

$\alpha$-SMA

RGD

BGN

BSA

CXCL8

CD26

CD74

COL1

COL3

$\mathrm{CM}$

CS

DMEM

EMEM

Echi

ELN

ELISA

ECM

FceR1

FBN

FN

FAK

HBSS

$\mathrm{IgE}$

IL-3

LI

LIF

LIFE

LUM

LOX

MMP1

\section{Full Name}

2,4-dinitrophenylated BSA

actin

alpha-smooth muscle actin

arginine-glycine-aspartic acid

biglycan

bovine serum albumin

$\mathrm{C}-\mathrm{X}-\mathrm{C}$ motif chemokine ligand 8

cluster of differentiation 26

cluster of differentiation 74

collagen type I

collagens type III

conditioned medium

connecting segment

Dulbecco's modified Eagle's medium

eagle's minimum essential medium

echistatin

elastin

enzyme-linked immunosorbent assay

extracellular matrix

Fc epsilonR1 alpha (FceR1)

fibrillin

fibronectin

focal adhesion kinase

hanks balanced salt solution

immunoglobulin E

interleukin-3

Lagerstroemia indica

Lagerstroemia indica flower

Lagerstroemia indica flower extract

lumican

lysyl oxidase

matrix metallopeptidase 1 


$\begin{array}{ll}\text { MMP3 } & \text { matrix metallopeptidase } 3 \\ \text { NHDF } & \text { normal human dermal fibroblast } \\ \text { PBS } & \text { phosphaste-buffered saline } \\ \text { RBL } & \text { rat basophilic leukemia } \\ \text { SA } & \text { striae albae } \\ \text { SD } & \text { striae distensae } \\ \text { SR } & \text { striae rubrae } \\ \text { TGF- } \beta & \text { transforming growth factor- } \beta \\ \text { TNF- } \alpha & \text { tumor necrosis factor- } \alpha \\ \text { VEGF-A } & \text { vascular endothelial growth factor A }\end{array}$

\section{References}

1. Al-Himdani, S.; Ud-Din, S.; Gilmore, S.; Bayat, A. Striae Distensae: A Comprehensive Review and Evidence-Based Evaluation of Prophylaxis and Treatment. Br. J. Dermatol. 2014, 170, 527-547. [CrossRef] [PubMed]

2. $\quad$ Keen, M.A. Striae Distensae: What's New at the Horizon? Br. J. Med Pract. 2016, 9 , 7.

3. Borrelli, M.R.; Griffin, M.; Ngaage, L.M.; Longaker, M.T.; Lorenz, H.P. Striae Distensae: Scars without Wounds. Plast. Reconstr. Surg. 2021, 148, 77-87. [CrossRef] [PubMed]

4. Shuster, S. The Cause of Striae Distensae. Acta Derm. Venereol. Suppl. (Stockh.) 1979, 59, 161-169.

5. McDaniel, D.H. Laser Therapy of Stretch Marks. Dermatol. Clin. 2002, 20, 67-76. [CrossRef]

6. Ud-Din, S.; McGeorge, D.; Bayat, A. Topical Management of Striae Distensae (Stretch Marks): Prevention and Therapy of Striae Rubrae and Albae. J. Eur. Acad. Dermatol. Venereol. 2016, 30, 211-222. [CrossRef]

7. Lee, K.S.; Rho, Y.J.; Jang, S.I.; Suh, M.H.; Song, J.Y. Decreased Expression of Collagen and Fibronectin Genes in Striae Distensae Tissue. Clin. Exp. Dermatol. 1994, 19, 285-288. [CrossRef]

8. Perez-Aso, M.; Roca, A.; Bosch, J.; Martínez-Teipel, B. Striae Reconstructed, a Full Thickness Skin Model That Recapitulates the Pathology behind Stretch Marks. Int. J. Cosmet. Sci. 2019, 41, 311-319. [CrossRef]

9. Sheu, H.-M.; Yu, H.-S.; Chang, C.-H. Mast Cell Degranulation and Elastolysis in the Early Stage of Striae Distensae. J. Cutan. Pathol. 1991, 18, 410-416. [CrossRef]

10. Kanata, M.; Oka, M.; Nagai, H.; Kunisada, M.; Nishigori, C. Urticariform Striae Distensae with Severe Pruritus and Pain in an Obese Woman. Eur. J. Dermatol. EJD 2011, 21, 799-800. [CrossRef]

11. Krüger-Krasagakes, S.; Czarnetzki, B.M. Cytokine Secretion by Human Mast Cells. Exp. Dermatol. 1995, 4, 250-254. [CrossRef] [PubMed]

12. Möller, A.; Henz, B.M.; Grützkau, A.; Lippert, U.; Aragane, Y.; Schwarz, T.; Krüger-Krasagakes, S. Comparative Cytokine Gene Expression: Regulation and Release by Human Mast Cells. Immunology 1998, 93, 289-295. [CrossRef] [PubMed]

13. Dabbous, M.K.; Walker, R.; Haney, L.; Carter, L.M.; Nicolson, G.L.; Woolley, D.E. Mast Cells and Matrix Degradation at Sites of Tumour Invasion in Rat Mammary Adenocarcinoma. Br. J. Cancer 1986, 54, 459-465. [CrossRef] [PubMed]

14. Krystel-Whittemore, M.; Dileepan, K.N.; Wood, J.G. Mast Cell: A Multi-Functional Master Cell. Front. Immunol. 2016, 6, 620. [CrossRef]

15. Wang, L.; Sikora, J.; Hu, L.; Shen, X.; Grygorczyk, R.; Schwarz, W. ATP Release from Mast Cells by Physical Stimulation: A Putative Early Step in Activation of Acupuncture Points. Evid. Based Complement. Alternat. Med. 2013, 2013, e350949. [CrossRef]

16. Shimbori, C.; Upagupta, C.; Bellaye, P.-S.; Ayaub, E.A.; Sato, S.; Yanagihara, T.; Zhou, Q.; Ognjanovic, A.; Ask, K.; Gauldie, J.; et al. Mechanical Stress-Induced Mast Cell Degranulation Activates TGF-B1 Signalling Pathway in Pulmonary Fibrosis. Thorax 2019, 74, 455-465. [CrossRef]

17. Zhang, D.; Spielmann, A.; Wang, L.; Ding, G.; Huang, F.; Gu, Q.; Schwarz, W. Mast-Cell Degranulation Induced by Physical Stimuli Involves the Activation of Transient-Receptor-Potential Channel TRPV2. Physiol. Res. 2012, 113-124. [CrossRef]

18. Rozario, T.; DeSimone, D.W. The Extracellular Matrix In Development and Morphogenesis: A Dynamic View. Dev. Biol. 2010 341, 126-140. [CrossRef]

19. Buck, C.A.; Horwitz, A.F. Cell Surface Receptors for Extracellular Matrix Molecules. Annu. Rev. Cell Biol. 1987, 3, 179-205. [CrossRef]

20. Krüger-Krasagakes, S.; Grützkau, A.; Krasagakis, K.; Hoffmann, S.; Henz, B.M. Adhesion of Human Mast Cells to Extracellular Matrix Provides a Co-Stimulatory Signal for Cytokine Production. Immunology 1999, 98, 253-257. [CrossRef]

21. Ra, C.; Yasuda, M.; Yagita, H.; Okumura, K. Fibronectin Receptor Integrins Are Involved in Mast Cell Activation. J. Allergy Clin. Immunol. 1994, 94, 625-628. [CrossRef]

22. Yasuda, M.; Hasunuma, Y.; Adachi, H.; Sekine, C.; Sakanishi, T.; Hashimoto, H.; Ra, C.; Yagita, H.; Okumura, K. Expression and Function of Fibronectin Binding Integrins on Rat Mast Cells. Int. Immunol. 1995, 7, 251-258. [CrossRef] [PubMed]

23. Fowlkes, V.; Wilson, C.G.; Carver, W.; Goldsmith, E.C. Mechanical Loading Promotes Mast Cell Degranulation via RGD-Integrin Dependent Pathways. J. Biomech. 2013, 46, 788-795. [CrossRef] [PubMed]

24. Komiyama, H.; Miyake, K.; Asai, K.; Mizuno, K.; Shimada, T. Cyclical Mechanical Stretch Enhances Degranulation and IL-4 Secretion in RBL-2H3 Mast Cells. Cell Biochem. Funct. 2014, 32, 70-76. [CrossRef] [PubMed] 
25. Wang, N.; Butler, J.; Ingber, D. Mechanotransduction across the Cell Surface and through the Cytoskeleton. Science 1993, 260, 1124-1127. [CrossRef]

26. Gilmore, S.J.; Vaughan, B.L.; Madzvamuse, A.; Maini, P.K. A Mechanochemical Model of Striae Distensae. Math. Biosci. 2012, 240, 141-147. [CrossRef]

27. Viennet, C.; Bride, J.; Armbruster, V.; Aubin, F.; Gabiot, A.-C.; Gharbi, T.; Humbert, P. Contractile Forces Generated by Striae Distensae Fibroblasts Embedded in Collagen Lattices. Arch. Dermatol. Res. 2005, 297, 10-17. [CrossRef]

28. Das, K. Study of Medicinal Plants in Nuhashpalli, Bangladesh. Bachelor's Thesis, Daffodil International University, Dhaka, Bangladesh, 2015.

29. Al-Snafi, A.E. A Review on Lagerstroemia Indica: A Potential Medicinal Plant. IOSR J. Pharm. 2019, 9, 36-42.

30. Yang, E.J.; Lee, J.S.; Song, B.B.; Yun, C.Y.; Kim, D.H.; Kim, I.S. Anti-inflammatory effects of ethanolic extract from Lagerstroemia indica on airway inflammation in mice. J. Ethnopharmacol. 2011, 136, 422-427. [CrossRef]

31. Ayoub, N.; Singab, A.B.; Labib, R.M. Chemical Constituents and Pharmacological Studies of Lagerstroemia Indica Phytopharmacology 2013, 4, 373-389.

32. Woo, K.W.; Sim, M.O.; Park, E.J.; Kim, M.S.; Suh, W.S.; Cho, H.W.; Kwon, H.C.; Park, J.C.; Lee, K.R. Chemical Constituents from the Stems of Lagerstroemia indica and Their Anti-oxidant Effect. Korean J. Pharmacogn. 2016, 47, $204-210$.

33. Beaven, M.A.; Metzger, H. Signal Transduction by Fc Receptors: The Fc Epsilon RI Case. Immunol. Today 1993, 14, $222-226$. [CrossRef]

34. Metzger, H. The Receptor with High Affinity for IgE. Immunol. Rev. 1992, 125, 37-48. [CrossRef] [PubMed]

35. Apgar, J.R. Increased Degranulation and Phospholipase A2, C, and D Activity in RBL Cells Stimulated through FcER1 Is Due to Spreading and Not Simply Adhesion. J. Cell Sci. 1997, 110, 771-780. [CrossRef] [PubMed]

36. Wierzbicka-Patynowski, I.; Niewiarowski, S.; Marcinkiewicz, C.; Calvete, J.J.; Marcinkiewicz, M.M.; McLane, M.A. Structural Requirements of Echistatin for the Recognition of Av $\beta 3$ and A5ß1Integrins*. J. Biol. Chem. 1999, 274, 37809-37814. [CrossRef]

37. Brockbank, E.C.; Bridges, J.; Marshall, C.J.; Sahai, E. Integrin B1 Is Required for the Invasive Behaviour but Not Proliferation of Squamous Cell Carcinoma Cells in Vivo. Br. J. Cancer 2005, 92, 102-112. [CrossRef]

38. Richardson, A.; Parsons, T. A Mechanism for Regulation of the Adhesion-Associated Proteintyrosine Kinase Pp125FAK. Nature 1996, 380, 538-540. [CrossRef]

39. Paszek, M.J.; Boettiger, D.; Weaver, V.M.; Hammer, D.A. Integrin Clustering Is Driven by Mechanical Resistance from the Glycocalyx and the Substrate. PLOS Comput. Biol. 2009, 5, e1000604. [CrossRef]

40. Borrelli, M.R.; Henn, D.; Mascharak, S.; Ngaage, L.M.; Griffin, M.; Patel, A.; Nazerali, R.; Lee, G.; Januszyk, M.; Wan, D.C.; et al. Abstract 79: Striae Distensae Are Rich In Mechanoresponsive And Cd26-Positive Human Dermal Fibroblasts And Exhibit Increased Profibrotic Signaling. Plast. Reconstr. Surg. Glob. Open 2020, 8, 51-52. [CrossRef]

41. Razzak, M.A.; Hossain, M.S.; Radzi, Z.B.; Yahya, N.A.B.; Czernuszka, J.; Rahman, M.T. Cellular and Molecular Responses to Mechanical Expansion of Tissue. Front. Physiol. 2016, 7, 540. [CrossRef]

42. Schwartz, M.A.; DeSimone, D.W. Cell Adhesion Receptors in Mechanotransduction. Curr. Opin. Cell Biol. 2008, 20, 551-556. [CrossRef]

43. Jaalouk, D.E.; Lammerding, J. Mechanotransduction Gone Awry. Nat. Rev. Mol. Cell Biol. 2009, 10, 63-73. [CrossRef]

44. Bradding, P.; Pejler, G. The Controversial Role of Mast Cells in Fibrosis. Immunol. Rev. 2018, 282, 198-231. [CrossRef]

45. Hua, Y. The Role of the Mast Cell in Skin Aging. J. Dermatol. Res. Ther. 2016, 2, 035. [CrossRef]

46. Behzad, H.; Sharma, A.; Mousavizadeh, R.; Lu, A.; Scott, A. Mast Cells Exert Pro-Inflammatory Effects of Relevance to the Pathophyisology of Tendinopathy. Arthritis Res. Ther. 2013, 15, R184. [CrossRef]

47. Ceci, C.; Lacal, P.M.; Tentori, L.; De Martino, M.G.; Miano, R.; Graziani, G. Experimental Evidence of the Antitumor, Antimetastatic and Antiangiogenic Activity of Ellagic Acid. Nutrition 2018, 10, 1756. [CrossRef]

48. Ríos, J.-L.; Giner, R.; Marín, M.; Recio, M. A Pharmacological Update of Ellagic Acid. Planta Med. 2018, 84, 1068-1093. [CrossRef]

49. Choi, Y.H.; Yan, G.H. Ellagic Acid Attenuates Immunoglobulin E-Mediated Allergic Response in Mast Cells. Biol. Pharm. Bull. 2009, 32, 1118-1121. [CrossRef]

50. Lam, V.; Kalesnikoff, J.; Lee, C.W.K.; Hernandez-Hansen, V.; Wilson, B.S.; Oliver, J.M.; Krystal, G. IgE Alone Stimulates Mast Cell Adhesion to Fibronectin via Pathways Similar to Those Used by IgE + Antigen but Distinct from Those Used by Steel Factor. Blood 2003, 102, 1405-1413. [CrossRef] 